\title{
RESEARCH OF REFUSE DERIVED FUEL USE WITH PYROLYSIS FURNACE
}

\author{
Nikolay Shein \\ The management \\ TK Ekotrans Ltd \\ Belgorod, Russia \\ energy_olver@mail.ru
}

\author{
Pavel Trubaev \\ Institute of Power Engineering, Information Technologies \\ and Operating Systems \\ BSTU named after V. G. Shukov \\ Belgorod, Russia \\ trubaev@gmail.com
}

\author{
Natalya Kornilova \\ Institute of Power Engineering, Information Technologies \\ and Operating Systems \\ BSTU named after V. G. Shukov \\ Belgorod, Russia \\ kornilovanata@ya.ru
}

\author{
Oleg Verevkin \\ Department of development \\ TK Ekotrans Ltd \\ Belgorod, Russia \\ energy_olver@mail.ru
}

\begin{abstract}
The study analyses methods of energy recovery of solid waste. A conclusion is reached that the most effective method for small-scale units is incineration in a pyrolysis furnace. Instrument measurements were used for evaluation of pyrolysis furnace incineration efficiency for cylindrical briquettes of pressed refuse wood in comparison to whole wooden pieces. Thermotechnical indicators of boiler efficiency and environmental indicators for incineration of different types of briquetted waste were determined; maximum ground level concentration values of harmful substances were calculated. Instrumental measurement of carbon monoxide, methane, phenol, benzene, sulfur dioxide, formaldehyde and hydrogen chloride content in stack gases was performed. The results led to a conclusion that incineration of briquetted refuse wood in pyrolysis furnaces is characterized by higher heat efficiency and lower emissions in comparison to direct burning of the refuse.
\end{abstract}

Keywords - RDF; pyrolysis boiler; wood fuel; moulded cakes; efficiency.

\section{INTRODUCTION}

Today the principal way of waste disposal for more than 95\% of waste in the Russian Federation is landfilling [1]. A disadvantage of this method is exclusion of vast areas from active use, degradation and further dissipation of suspended substances coming from the waste as well as from its degradation products by ground and open waters, release of gaseous degradation products into the atmosphere [2]. Currently there are no working projects for disposal of solid domestic waste with low-scale electricity production [3]

The objective of this study is to analyze possible methods of solid domestic waste use in energy production and experimental study of refuse derived fuel (RDF) incineration in a low-power pyrolysis furnace with the aim to determine energy efficiency and environmental characteristics of the process.

\section{THE METHODS OF ENERGY CONVERSION OF WASTES}

The methods of energy conversion of solid wastes may be

The article was prepared within development program of the Flagship Regional University on the basis of Belgorod State Technological University named after V.G. Shukhov classified in the following way:

- Bioconversion (energy product - gaseous fuel).

- Direct incineration (energy product - heat energy).

- Gasification (energy product - gaseous fuel and heat energy)

- Pyrolysis (energy product - solid, liquid and gaseous fuel).

Let us consider the methods that have been listed.

\section{A. Bioconversion}

Biogas is a mixture of methane and carbon dioxide that is formed during anaerobic fermentation of organic waste in a diverse range of special reactors, called fermenters. Advantages of biogas stations - disinfection of organic farm waste, a constant level of availability and energy production, maximum use of installed capacity. The main disadvantage of the biogas energy production is high capital costs per unit of power. Cost of $1 \mathrm{~kW}$ of installed electrical power of a biogas station fluctuates between $€ 2000$ for large-scale stations with power exceeding $10 \mathrm{MW}$ to $€ 6000 \ldots 7000$ for stations under 1 MW operating on non-economic feed with a high humidity and low fuel value [4].

\section{B. Direct incineration}

Incineration of flammable waste is the most universal, simplest and the most reliable method of waste neutralization. To ensure stable burning and absence of harmful emission the waste is burnt at a temperature of no lower than $1200-1300^{\circ} \mathrm{C}$. There are two main methods of solid waste incineration: layered burning (with movable or immovable grate or chain grating) and dust burning (in a suspended flock layer or in a fluidized bed). The first method is easier to implement, while the second one allows achieving more perfect waste combustion.

Toxic components undergo oxidation, thermal decay and other chemical transformations that turn them into mainly 
harmless gases $\left(\mathrm{CO}_{2}, \mathrm{H}_{2} \mathrm{O}, \mathrm{N}_{2}\right)$ and solid residues (metal oxides, salts), thus providing high sanitary and hygienic efficiency of the fire methods of waste neutralization. The main disadvantage of direct incineration is pollution of the atmosphere with harmful emissions in case of low temperature in the combustion zone and low combustion temperature. However, PAPER [5] states that landfilling is more dangerous than incineration. Adiabatic combustion temperature of waste can be raised and harmful emission reduced by means of preheating both the waste and the combustion air from recuperated effluent heat, by air enrichment and by admission of fuel to the waste [6].

\section{Waste gasification}

Gasification is a partial oxidation process that results in transformation of low fuel value waste into high fuel value synthesis gas. Gasification is implemented in mechanized underground gas generators with rotating grates and removal of solid slag; in gas generators with a fluidized layer; in underground gas generators with air blasting and removal of liquid slag (blast furnace method).

Waste processing by gasification has the following advantages in comparison to incineration: flammable gases obtained may be used as energy producing and process fuel, while in case of incineration only energy production (by production of steam or hot water) is practical; emission of ash and sulfur compounds into the atmosphere is reduced [7]. The disadvantages of the method are necessity for rigorous sorting of waste to exclude low-melting components, instability of the process, formation of tars and slags polluting the equipment

\section{Pyrolysis of waste}

Pyrolysis is thermal decomposition of flammable waste under scarce oxygen conditions.

Oxidative pyrolysis (one of the stages of gasification process) is a process of thermal decomposition of waste during their partial incineration or direct contact with fuel combustion products. Subsequently the gaseous products of decomposition are mixed with combustion products and the mixture is afterburned. A solid carbon residue (coke) is formed during the oxidative pyrolysis, while the solid residue of the gasification process is a mineral product (ash and slag). Constructive separation of the solid waste pyrolysis zone and fire channel excludes ingress of carbon and dust particles into the effluent gas stream, thus preventing repeated synthesis of dioxins.

Dry distillation (dry pyrolysis) is a method of thermal processing of waste in the absence of oxygen. It results in formation of pyrolysis gas with high combustion heat, liquid products and solid carbon residue.

According to several sources, pyrolysis appears as the most efficient economically and has the lowest environmental impact $[8,9]$. However, opinions vary on practicability of dry pyrolysis in solid household wastes and some types of industrial wastes [10].

\section{E. Conclusions}

The analysis undertaken allows one to conclude that there is no universal waste disposal method fitting modern economic and environmental requirements. The following principles of thermal disposal of the solid household waste may be formulated to minimize the environmental impact:

- thermal decomposition with minimal amount of oxygen;

- maintaining the temperature in the combustion/decomposition zone at the level of at least $900^{\circ} \mathrm{C}$ and the time spent in the combustion zone at the minimum level of 2 seconds;

- preliminary homogenization of the components, mixing of the wastes being treated inside the furnaces and reactors.

The results of the analysis allows one to conclude that for small-scale units (up to 200-300 kW) a combination of direct incineration and pyrolysis in pyrolysis furnaces is the most efficient method of waste disposal for energy generation. Besides that, the pyrolysis process allows for processing of a wide range of hard-to-dispose-of wastes (car tires, plastics, spent oil), the ash formed is of high density, while the equipment is of low power requirements.

\section{METHODOLOGY}

This study is concerned with thermotechnical testing of a pyrolysis boiler by means of measuring instruments: ultrasound flow meter, gas analyzers for effluent gases and multicomponent mixtures, thermometers and pyrometers. It resulted in determination of thermotechnical efficiency indicators of the boiler and its environmental indicators for incineration of different types of briquetted wastes.

\section{MAIN PART}

\section{A. Description of the pyrolysis boiler}

A functioning boiler house where the testing has taken place is located in the city of Belgorod, Russia and is intended for production of hot water for two administrative buildings with the area of 600 and $1900 \mathrm{~m}^{2}$. Heat duty from the thermal calculation made for the buildings is equal to 32 and $86 \mathrm{~kW}$ respectively and exceeds the rated capacity for the buildings approximately by a factor of 2 (rated heat duty of the buildings is 13 and $41 \mathrm{~kW}$ respectively). The heating is provided through a closed dependent system.
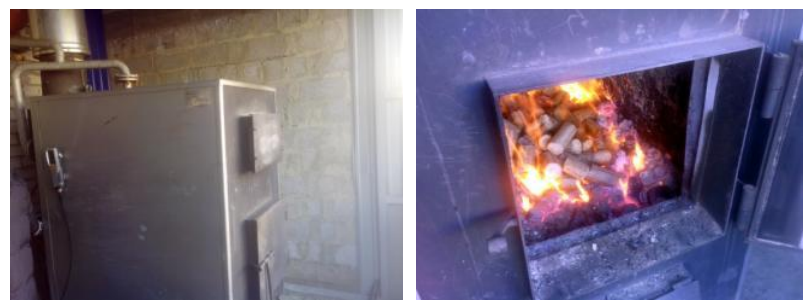

Fig. 1. Pyrolysis boiler

The type KO-100 boiler (Fig. 1) is an all-welded steel construction consisting of two combustion chambers. The bottom chamber is a gasification chamber, where the fuel is decomposed at high temperature into the solid and volatile fractions under low oxygen conditions. The top chamber is for afterburning of the produced gas. There is an unregulated window for air supply and a regulated air supply door, which according 
to the operating manual shall be opened only during the boiler ignition. The flue gas stack is provided with a dumper.

Pyrolysis boiler allows providing prolonged burning of one batch of fuel and makes it possible to use large waste fragments without prior shredding.

As per data sheet specification the boiler has the following characteristics:

- Thermal rating $-100 \mathrm{~kW}$.

- Efficiency - 80-90\%.

- Working temperature $-90^{\circ} \mathrm{C}$.

- Working pressure -2-3 bar.

- Furnace volume $-0.65 \mathrm{~m}^{3}$.

- Weight $-950 \mathrm{~kg}$.

- Fuel consumption $-0.36 \mathrm{~m}^{3} /$ day.

The measurements were carried out for burning whole pieces of wood and timber sleepers, as well as cylindrical briquettes of pressed pulverized wood with the diameter of 50 $\mathrm{mm}, 100-200 \mathrm{~mm}$ long and with a density of $800 \mathrm{~kg} / \mathrm{m}^{3}[11$, 12]. The following types of fuel were burned in the furnace:

- timber sleepers (Fuel 1);

- $\quad$ timber - pine (Fuel 2);

- waste wood: window frames, doors, furniture (Fuel 3);

- cylindrical wood briquettes (Fuel 4);

- RDF (Refuse-derived fuel): cylindrical briquettes of sorted solid household waste (Fuel 5);

- Mixture of wood pellets 50\% and RDF 50\% (Fuel 6).

B. Determination of thermal efficiency of the pyrolysis boiler in burning of briquetted fuel

During the study the burning of briquetted fuel was compared to that of whole wood, the latter being the boiler's design fuel. The testing method included:

1. Ramping up the boiler to nominal rating (water temperature downstream of the boiler in accordance with the heating curve).

2. Water temperature measurement in supply and return pipelines, flow measurement in the return pipeline with an ultrasound flow meter Panametrics PT878 and pyrometer/contact thermometer Testo-845 (at a 3 minute interval).

3. Temperature measurement and composition analysis $\left(\mathrm{O}_{2}, \mathrm{CO}, \mathrm{CO}_{2}\right)$ of flue gas by means of the Testo 330-1 LL gas analyzer (1 minute interval).

Heat output, boiler efficiency, heat loses and specific consumption of natural and reference fuel were calculated from the measurement data. The boiler efficiency was determined by the indirect heat balance method.

For firewood burning it was established that the burning process is stable and is disturbed only by adding a new batch of fuel. Dumper closing did not disturb the combustion condition (increased $\mathrm{CO}$ or $\mathrm{O}_{2}$ ), however, it led to significantly lower flue gas temperature. The boiler efficiency in stable condition is $64-74 \%$, which is lower that its data sheet value.

Two series of tests were conducted, one to evaluate boiler operation with air supply door closed, and the second one with partially obstructed air supply window. The results of the test are given in Fig. 2.
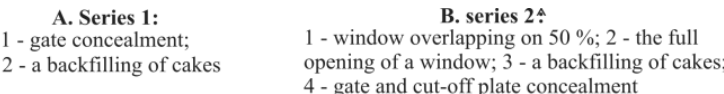
4 - gate and cut-off plate concealment
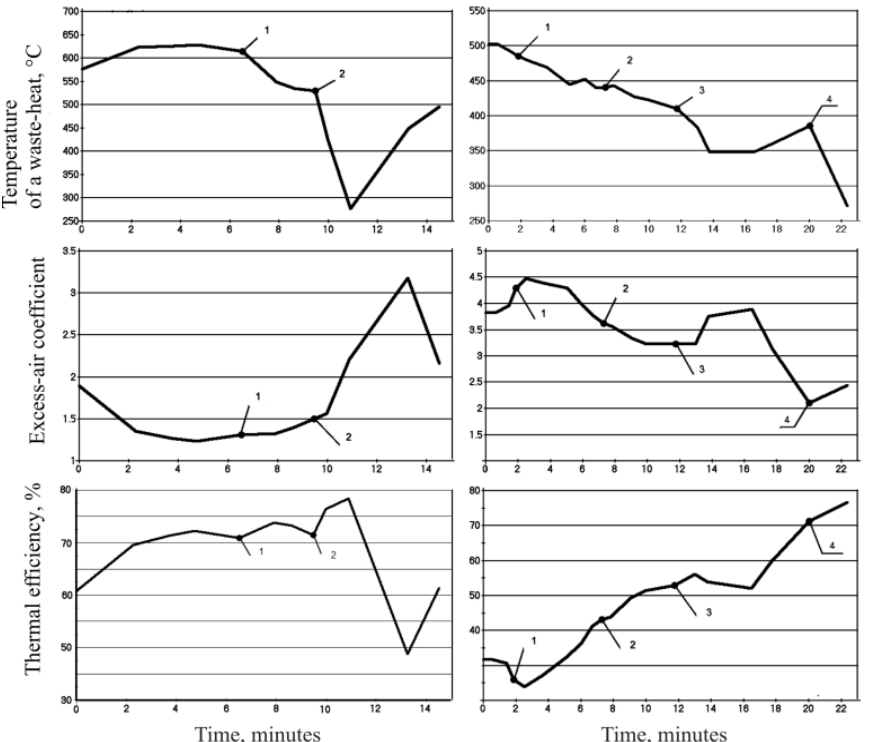

Fig. 2. Measurements for wood briquettes burning

As evident from the results, closing air supply of the pyrolysis chamber led to disturbance of the boiler operating mode. The boiler efficiency in stable condition is $60-74 \%$.

Conclusions from thermotechnical testing of the boiler with briquette burning are as follows:

1. An hourly average power of the boiler while burning the briquetted wood is $95.6 \mathrm{~kW}$, which is $5.6 \%$ higher that the hourly average power of the same boiler burning firewood

2. Efficiency of the boiler never exceeded $74 \%$, the average efficiency in the stable mode was $70 \%$, which is lower than the data sheet value of $84 \%$. The fuel burns perfectly, which is evident from the low $\mathrm{CO}$ level in flue gas.

\section{Estimation of emissions for combustion of different types of waste in the pyrolysis boiler}

The testing lasted for three days and included determination of content of the following components in the boiler flue gas: carbon monoxide, methane, phenol, benzene, sulfur dioxide, formaldehyde, hydrogen chloride. The measurement were made with a GANK-4 portable multi-component gas analyzer.

The measurements (Table 1) were used to calculate ground level concentration values of harmful substances as per method [13] for the conditions of gas-air mixture emission from a single point source with a round orifice. The following data were used in calculations: flue gas duct orifice height is 
$10 \mathrm{~m}$ above ground; diameter of the flue gas orifice is $0.25 \mathrm{~m}$; ture is $0^{\circ} \mathrm{C}$; the average gas-air mixture emission rate is $1 \mathrm{~m} / \mathrm{s}$. gas temperature at the orifice is $200^{\circ} \mathrm{C}$; ambient air tempera-

TABLE I. CONCENTRATION OF HARMFUL SUBSTANCES FOR COMBUSTION OF DIFFERENT TYPES OF FUEL, MG/M ${ }^{3}$

\begin{tabular}{|c|c|c|c|c|c|c|c|c|c|c|}
\hline No. & Fuel & $\mathrm{NO}_{2}$ & NO & CO & $\mathbf{C H}_{4}$ & Phenol & Benzene & $\mathbf{S O}_{2}$ & Formaldehyde & HCl \\
\hline & \multicolumn{10}{|c|}{ Results of measurements from samples taken in the flue duct behind the boiler } \\
\hline 1 & Timber sleepers & 12.2 & 11.4 & 123 & 237 & $<0.0015$ & 99.1 & 6.44 & 1.97 & 0.472 \\
\hline 2 & Firewood (pine) & 0.5 & 0.5 & 204 & 203 & 0.786 & $<2.5$ & $<0.025$ & $<0.0015$ & 1.73 \\
\hline 3 & Waste wood (window frames, doors, furniture) & 8.9 & 53.6 & 267 & 2328 & 12 & 166 & 4.71 & 14.6 & 0.326 \\
\hline 4 & Wood pellets & 11.6 & 13.6 & 267 & 1095 & 0.777 & $<2.5$ & $<0.025$ & 0.898 & 1.6 \\
\hline 5 & RDF & 0.9 & 6.6 & 94.1 & 1686 & 0.063 & 29.7 & $<0.025$ & 7.88 & 0.151 \\
\hline \multirow[t]{2}{*}{6} & A mixture of wood pellets and RDF & 8.6 & 57.3 & 267 & 1164 & $<0.0015$ & 65.3 & $<0.025$ & 9.1 & 0.874 \\
\hline & \multicolumn{10}{|c|}{ Calculated ground level concentration $\left(C_{i}\right)$} \\
\hline 1 & Timber sleepers & 0.0001 & 0.0001 & 0.001 & 0.002 & $<0.013 \cdot 10^{-6}$ & 0.0009 & $57.4 \cdot 10^{-6}$ & $17.6 \cdot 10^{-6}$ & $4.2 \cdot 10^{-6}$ \\
\hline 2 & Firewood (pine) & $4.5 \cdot 10^{-6}$ & $4.5 \cdot 10^{-6}$ & 0.002 & 0.002 & $7 \cdot 10^{-6}$ & $<22,3 \cdot 10^{-6}$ & $<0.223 \cdot 10-^{6}$ & $0.013 \cdot 10^{-6}$ & $1.54 \cdot 10^{-6}$ \\
\hline 3 & Waste wood (window frames, doors, furniture) & $79.4 \cdot 10^{-6}$ & 0.0005 & 0.002 & 0.021 & 0.0001 & 0.0015 & $42 \cdot 10^{-6}$ & $130.2 \cdot 10^{-6}$ & $2.9 \cdot 10^{-6}$ \\
\hline 4 & Wood pellets & 0.0001 & 0.0001 & 0.002 & 0.010 & $6.9 \cdot 10^{-6}$ & $<22.3 \cdot 10^{-6}$ & $<0.223 \cdot 10-^{6}$ & $8 \cdot 10^{-6}$ & $1.43 \cdot 10^{-6}$ \\
\hline 5 & RDF & $8 \cdot 10^{-6}$ & $58.9 \cdot 10^{-6}$ & 0.001 & 0.015 & $0.6 \cdot 10^{-6}$ & 0.0003 & $<0.223 \cdot 10-^{6}$ & $70.3 \cdot 10^{-6}$ & $1.3 \cdot 10^{-6}$ \\
\hline \multirow[t]{2}{*}{6} & A mixture of wood pellets and RDF & $76.7 \cdot 10^{-6}$ & 0.0005 & 0.002 & 0.010 & $<0.013 \cdot 10^{-6}$ & 0.0006 & $<0.223 \cdot 10-^{6}$ & $81.2 \cdot 10^{-6}$ & $7.8 \cdot 10^{-6}$ \\
\hline & \multicolumn{10}{|c|}{ Maximum allowable concentration [14] } \\
\hline $\begin{array}{l}- \\
-\end{array}$ & $\begin{array}{l}\text { Atmosphere of populated areas } \\
\text { Short-term exposure limit } \\
\text { daily average exposure limit } C_{M A C i}\end{array}$ & $\begin{array}{l}0.085 \\
0.04\end{array}$ & $\begin{array}{l}0.4 \\
0.06 \\
\end{array}$ & $\begin{array}{l}5 \\
3 \\
\end{array}$ & $\begin{array}{l}- \\
- \\
\end{array}$ & \begin{tabular}{|l}
0.01 \\
0.003 \\
\end{tabular} & $\begin{array}{l}0.3 \\
0.1 \\
\end{array}$ & \begin{tabular}{|l}
0.5 \\
0.05 \\
\end{tabular} & $\begin{array}{l}0.035 \\
0.003 \\
\end{array}$ & - \\
\hline- & In the atmosphere of production facilities & 2 & 5 & 20 & 7000 & 0.1 & $15(5)$ & 10 & 0.5 & 5 \\
\hline- & Substance hazard category $k_{i}$ & 4 & 3 & 4 & 4 & 3 & 2 & 3 & 2 & 2 \\
\hline
\end{tabular}

The obtained values were compared with the maximum allowable concentration (MAC) values of the harmful substances given in the regulations [14]. For all the considered indicators, the calculated ground level concentration values have not exceeded the MAC values. In most cases it is significantly below the limit. This finding supports the claim made in a number of sources that one of advantages of pyrolysis is a significant reduction in emissions [15-17].

Total emission criterion $C$ was calculated to compare different types of waste (Fig. 3); it is a sum of ratios of calculated ground level concentration values $C_{i}$ to daily average exposure limits $C_{M A C i}$, with coefficient $k_{i}$ taking into account the hazard category of each substance:

$$
C=\frac{1}{N} \sum k_{i} \frac{C_{i}}{C_{M A C i}} 100 \%
$$

where $N$ is the number of components.

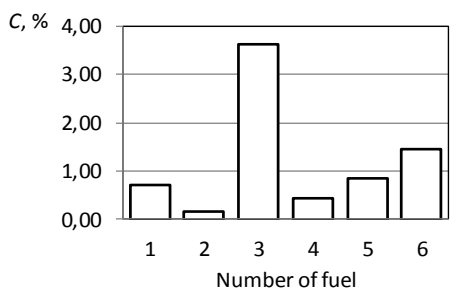

Fig. 3. Measurements for wood briquettes burning

The highest emission values for Fuel 3 (window frames, doors, furniture) are due to presence of resins and paint in the waste. Combustion of RDF (Fuel 5 and Fuel 6) does not lead to increase in harmful emissions.

The obtained results are not a complete characteristic of the mentioned types of fuel, due to the fact that the combus- tion mode (temperature and excess air) influence the emission as well as the fuel content, however, it allows for a qualitative comparison of the environmental characteristics of different types of fuel.

To determine the emission indicators, a series of measurement was conducted in different boiler operating modes. The following types of fuel were used:

- RDF: Mixture of wood 70\% and plastic 30\% (Fuel 7).

- RDF: Mixture of wood 50\% and plastic 50\% (Fuel 8).

A boiler with grating was used to burn the fuel. The fuel was preprocessed into pressed briquettes of pre-shredded waste $[10,11]$ with a diameter of $50 \mathrm{~mm}$ and a length of up to $400 \mathrm{~mm}$ (Fig. 1). Temperature of the fuel layer measured at the grating by a pyrometer was found to be $670-760^{\circ} \mathrm{C}$.

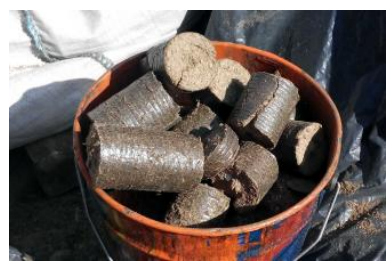

Fig. 4. Wood briquettes

Emission content for different flue gas temperatures behind the boiler is shown in Fig. 5 . 

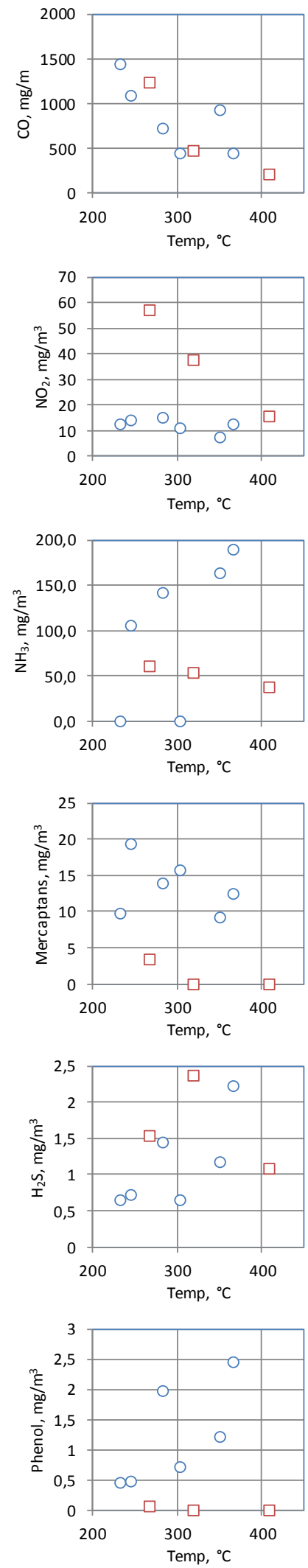

Fig. 5. Dependence of emissions on flue gas temperature

Emissions from the combustion bed boiler significantly exceed those from the pyrolysis boiler.
Dependence of harmful emissions on the operating parameters of the boiler were found only for $\mathrm{CO}$ concentration and flue gas temperature (correlation coefficient -0.80 ) or excess air ratio $(-0.84)$. No dependence was found between the content of other emissions and either $t_{\mathrm{OG}}$ or $\alpha$ (correlation coefficient module does not exceed 0.39). No correlations between content of different types of emission were found as well. Thus, the emission content for boiler operating range does not depend on the operating mode, with the exception for combustion efficiency, characterized by $\mathrm{CO}$ content.

\section{CONCLUSION}

A significant reduction of emissions allows using the pyrolysis boiler incineration as a method of waste neutralization in household heating, e.g., in automated heat supply systems of buildings and settlements. However, it should be noted that dioxins concentrations were not analyzed during this study.

\section{SUMMARY}

The study allows for conclusion that neutralization of solid waste by pressing them into cylindrical briquettes with the diameter of $50 \mathrm{~mm}$, length of 100-200 mm, and density of 800 $\mathrm{kg} / \mathrm{m}^{3}$, which is characterized as more efficient (the average power is higher by 5.6\%) compared to burning the whole wood fragments.

Measurement of carbon monoxide, methane, phenol, benzene, sulfur dioxide, formaldehyde and hydrogen chloride in flue gas showed that for all the combusted materials studied, the calculated ground level concentration values do not exceed MAC values and, in most cases, they are significantly lower. These findings support that the pyrolysis boilers are characterized by lower emission level compared to direct combustion of waste. Emission content in the flue gases does not depend on operating parameters of the boiler, with the exception of carbon monoxide which serves as an indicator of combustion efficiency

\section{References}

[1] L. Ia. Shubov, M. E. Stavrovskiy, D. V. Shehirev, Tekhnologii othodov (tekhnologicheskie protcessy' $\mathrm{v}$ servise) [Technologies of waste (technology processes in service)], Moscow: RSUTS, 2006.

[2] Z. I. Alexanderovskoy, Sanitarnaia ochistka gorodov ot tverdy`kh by` tovy`kh othodov [Sanitary cleaning of the cities from municipal solid waste], Moscow: Stroiyzdat, 1977.

[3] I. Yu. Egorov, "Tiazhelaia ekologicheskaia situatciia stanet odnim iz glavnykh draiyverov rosta [The difficult ecological situation will become one of the main drivers of growth]", Energetika i promyshlennost [Power and industry], 2014, № 2, URL: http://esco.co.ua/journal/industry/2014_2/art245.html.

[4] B. I. Levin, Ispol zovanie tverdy`kh by`tovy`kh othodov v sistemakh e`nergosnabzheniia [Use of municipal solid waste in power supply systems], Moscow: Energoizdat, 1982.

[5] E. G. Vatcet, M. O. Shpakov, S. S. Timofeeva, "Waste to income: ways of processing of municipal solid waste. [Othody $\mathrm{v}$ dohody: sposoby pererabotki tverdyh bytovyh othodov]", 2th Conf. Problems of sustainable development of society in Irkutsk, pp. 57-60, 1997.

[6] A.V.Smagin, V.V. Guseva, "Vozobnovliaemy`e istochniki e`nergii osnova al ternativnoi teploenergetiki [Renewable energy resources - a basis of alternative heat-and-power engineeering]." URL: http://esco.co.ua/journal/2009_4/art135.htm.

[7] Resource Recovery to Approach Zero Municipal Waste, ed. Mohammad J. Taherzadeh,Tobias Richard, Boca Raton: CRC Press, 2016. 
[8] D. Chen, L.Yin, H. Wang, P. He, "Pyrolysis technologies for municipal solid waste: A review", Waste Management, Vol. 34, Issue 12, pp. 24662486, December 2014. DOI: 10.1016/j.wasman.2015.01.022

[9] K. Tadao, H. Masakatsu, Water Res., Vol. 16, Issue 1, pp. 1569-1575, 1982.

[10] S. N. Glagolev, V. S. Sevostyianov, S. V. Sverguzova, I. G. Shaiyhiev, V. I. Uralskiy, M. V. Sevostyianov, D. D. Fetisov and L. I. Shinkarev, "Tekhnologicheskie kompleksy' i oborudovanie dlia pererabotki tekhnogenny kh materialov [Technology stacks and equipment for processing of technogenic materials]", Bulletin of KTU, No 10 (15), pp. 198-200, 2012.

[11] S. N. Glagolev, V. S. Sevostyianov, A. M. Gridchin, V. I. Uralskiy, M. V. Sevostyianov and V. V. Iadykina, "Resurso-energosberegaiushchie moduli dlia kompleksnoy utilizatcii tekhnogennykh materialov [Resource and energy saving modules for complex recovery of technogenic materials]", Bulletin of BSTU named after V. G. Shukhov, No 6, pp. 102-106, 2013.

[12] "Metodika rascheta koncentratcii' $v$ atmosfernom vozdukhe vredny'kh veshchestv, soderzhashchikhsia v vy`brosakh predpriiatii` (OND-86) [Method of calculation of concentration in the atmospheric air of the harmful substances which are contained in emissions of the enterprises]", Leningrad: Gidrometeoizdat, 1986.

[13] "Predelno dopustimye koncentratcii (PDK) zagriazniaiushchikh veshchestv v atmosfernom vozdukhe naselennykh mest GN 2.1.6.1338-
03 [The Maximum Allowable Concentrations (MAC) values of pollutants in the atmosphere of the inhabited locations ])", Moscow, 2003.

[14] I. O. Korovin, "Issledovanie piroliznoy utilizatcii uglesoderzhashchikh tvyordykh bytovykh othodov [A Study of pyrolysis energy recovery of carbonaceous municipal solid waste]", Cand. diss., Tiumen, 2003.

[15] S. K. Sergeev, A. N. Potapenko, A. V. Belousov, E. A. Potapenko, "Matematicheskie modeli upravleniia protcessami teplosnabzheniia zdanii` dlia avtomatizirovanny`kh sistem upravleniia [Mathematical models of process management for building heat supply automated control systems]", Bulletin of BSTU named after V. G. Shukhov, No 1, pp. 113-117, 2007.

[16] A. V. Belousov, Yu. A. Koshlich, A.B. Bystrova. "Perspektivy primenenija sovremennyh statisticheskih determinirovannyh metodov prognozirovanija $\mathrm{v}$ sistemah monitoringa jenergopotreblenija [Application Prospects of the modern statistically determined forecasting methods in energy consumption monitoring systems]" Bulletin of BSTU named after V. G. Shukhov, No 4, pp. 192-196, 2012.

[17] N.V. Kornilova, P.A. Trubaev, "The determination of harmful emissions of a hot-water boiler for the incineration of solid wastes of various types [Opredelenie vrednykh vybrosov vodogreinogo kotla pri szhiganii tverdykh othodov razlichnogo vida]", International Scientific Research Journal, No 10 (52), Part 2, pp. 123-126, 2016. DOI 10.18454/IRJ.2016.52.191. 